\title{
Blood Clams Community (Anadara granoasa) in The Eastern Coastal Waters of Banyuasin Regency South Sumatera
}

\author{
Rini Setianingsih ${ }^{1, *}$, Hilda Zulkifli ${ }^{1}$, Zazili Hanafiah $^{1}$ \\ Jl Padang Selasa, Bukit Besar Palembang 30129, Indonesia \\ *Corresponding author. email: rini_setianingsih22@yahoo.com \\ Article history

\begin{tabular}{llll} 
Received & Received in revised form & Accepted & Available online \\
25 February 2016 & 22 March 2016 & 31 March 2016 & 15 April 2016 \\
\hline
\end{tabular}

${ }^{1}$ Department of Natural resources management, Faculty of environmental management, Graduate Program, Sriwijaya University

\begin{abstract}
This research aimed to study existence of blood clams population and the environmental factors that affect them. This research was conducted in the coastal waters of Banyuasin in February 2015. The blood clamp sample was collected using Ekman Grab at low tide. From the observation in the research site, the highest population density was $60 \mathrm{ind} / \mathrm{m} 2$ with clay substrate texture, while the lowest density was $20 \mathrm{ind} / \mathrm{m}^{2}$ on the dusty clay substrate. Blood clams population was not found on the sand substrate texture station. Morphometric data showed that the blood clam population in the research site, including the medium category with $b<3$ growth pattern (allometric negative). The results of PCA analysis proved that the habitat texture and sediment organic habitats were dominant factors besides the chemical physics environmental factors of the waters (temperature, salinity, $\mathrm{pH}$ ).
\end{abstract}

Keywords: Blood clams, density, morphometric, PCA

\begin{abstract}
Abstrak (Indonesian): Penelitian ini bertujuan untuk mempelajari keberadaan populasi kerang-darah dan faktor lingkungan yang mempengaruhinya. Penelitian ini dilakukan di perairan pesisir Banyuasin pada bulan Februari 2015. Sampel kerang-darah diambil dengan menggunakan Ekman Grab pada saat air surut. Dari hasil pengamatan pada lokasi penelitian, kepadatan populasi kerang-darah tertinggi adalah $60 \mathrm{ind} / \mathrm{m}^{2}$ dengan tekstur substrat lempung, sedangkan kepadatan terendah adalah $20 \mathrm{ind} / \mathrm{m} 2$ pada substrat lempung berdebu. Populasi kerang-darah tidak ditemukan pada stasiun dengan tekstur substrat pasir. Data morfometrik menunjukkan bahwa populasi kerang-darah di lokasi penelitian termasuk kategori sedang dengan pola pertumbuhan $b<3$ (allometrik negatif). Hasil analisis PCA membuktikan bahwa tekstur habitat dan bahan organik sedimen merupakan faktor dominan di samping faktor lingkungan fisika kimia perairan (suhu, salinitas, $\mathrm{pH}$ ).
\end{abstract}

\section{Kata kunci: Kerang-darah, kepadatan, morfometrik, PCA}

\section{Introduction}

Blood clams are classified as soft animal, Bivalvia class, Arcidae Familia and Anadarinae subfamily with economic value as source of protein [1]. Blood clams live in intertidal areas and spread widely in Southeast Asia, especially Indonesia, Malaysia, and Thailand [2] Blood clams have been used by humans as a food source with high protein content, low in fat and rich in omega 3 [3]. Blood clam is one of the fisheries resources commodities in South Sumatra. The fishermen can collect eight sacks per vessel of clams in a day. One sack contains $30 \mathrm{~kg}$ of blood clams. According to the Sea Waters Capture Fisheries Statistics Agency (2001-2007) in Septiftitri et al [4], the production blood clams in 2007 were $578.70 /$ ton year, meanwhile in 2012 the production of blood clams decreased to be 3,083 / ton per year [5].
Considering the utilization of blood clams to increase the income of fishermen and maintain the ecosystem balance in nature. So that an effort is required to gather the information about the density which is seen from several environmental parameters in the blood clams' habitat. Environmental factors that affect the density of blood clams are temperature, $\mathrm{pH}$, turbidity, DO, salinity, stream, substrate and organic material.

This research aimed to study the blood clams density and environmental factors that influenced them. Information from this research can be used as an input that can be used as the basis for blood clams resource management in nature, so that their presence can continue and also can increase the income of fishermen near the Banyuasin coastal.

\section{Experimental Sections}


Blood clams sampling was done in February 2015 in the Banyuasin waters South Sumatera (Figure 1). Determination of sampling stations was done by using purposive sampling method which was based on the characteristics of blood clams habitat. Determination of the location of observation station was assumed based on the representatives of research areas. There were 6 stations which were observed. At each station, there were five points sampling observation at a distance of 30 $\mathrm{m}$

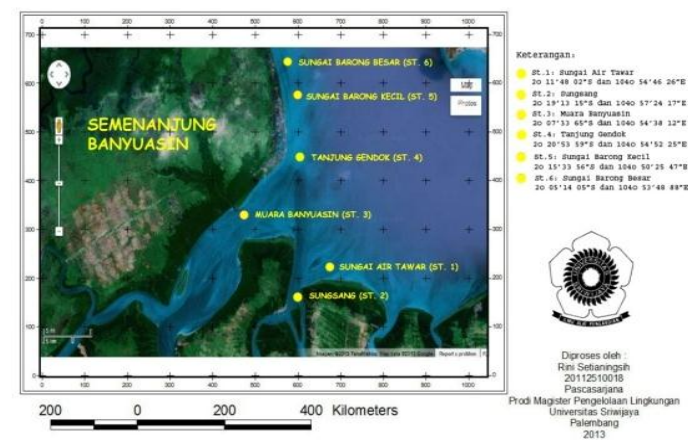

Figure 1. Research Location

The sampling of blood clams population (Figure 2. Sample of blood clams population sampling) was done by spreading the transect line perpendicular from the shoreline towards the sea as far as 150 meters. Furthermore, at every 30 meters, blood clams were collected using an Ekman Grab and put into a $20 \times 20 \mathrm{~cm}$ box. The sampling of blood clams population was done during low tide.

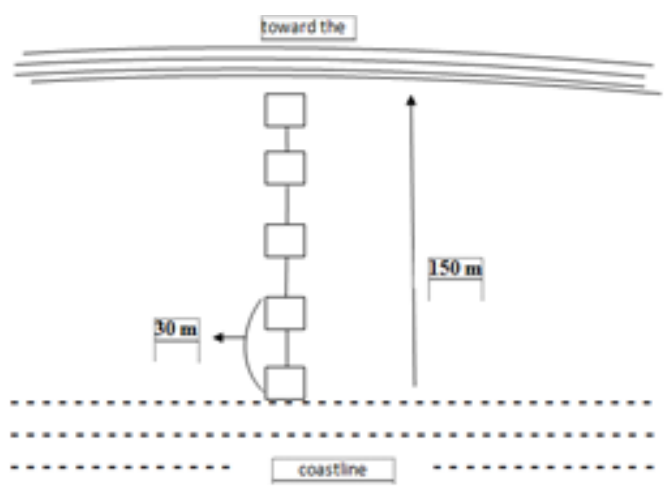

Figure 2. Sample of blood clams population sampling

The measurement of waters quality was simultaneously done with the sampling of blood clams at each observation stations. The measurement of waters quality parameters was directly conducted in the field including: salinity, temperature, $\mathrm{pH}$, brightness, stream, $\mathrm{pH}$ and DO. Sediment sampling at each stations was done using Ekman Grab. The sediment samples as many as $\mathbf{5 0 0}$ grams were taken and analyzed in the Agricultural Sciences Laboratory University of Sriwijaya. The fractions and organic materials were measured using hydrometer method [6].

\subsection{Population Density}

Population density shows the average of individual clam species per plot from the overall samples observed [7] using formula:

$$
D=\frac{A}{B} \times 10.000
$$

Where:

D : Density (individu $/ \mathrm{m}^{2}$ )

A : Total of individual

B : Area $\left(\mathrm{cm}^{2}\right)$

\subsection{Morphometric}

According to research done by Mulki et al (2012), blood clams populations are classified into three length classes, which are small size $(1,0 \mathrm{~cm}-2,0 \mathrm{~cm})$, medium size $(2.1 \mathrm{~cm}-3.0 \mathrm{~cm})$, big size $(>3,1 \mathrm{~cm})$. The relation between shell length and total weight is analyzed using [8].

$$
\mathrm{W}=\mathrm{aL}^{\mathrm{b}}
$$

Where $\mathrm{W}$ is the total weight, $\mathrm{L}$ is the length of shells and $\mathrm{a} / \mathrm{b}$ are constants. If the value of $\mathrm{b}=3$, then the growth is isometric which is the length and weight are balance. If $b<3$ then the growth is negative allometric, which is meant that the length growth is faster than the weight growth (thin clams). If $b>3$ then the growth is positive allometric which is meant that the weight growth is faster than the length growth (fat clamps) [9].

\subsection{Relation between Waters Parameters and Density of Blood Clams}

An analytical approach of principal component using SPSS 22 software can be used to understand the relation between density of blood clams and characteristics of their habitat.

\section{Result and Discussion \\ 3.1. Density}

The density of blood clams from all research locations can be seen in (Figure 3). The highest density found in station VI was $60 \mathrm{ind} / \mathrm{m}^{2}$ and the lowest density at station I was $20 \mathrm{ind} / \mathrm{m}^{2}$. Blood clams populations in station I, III, IV were mainly found at distance of 0-100 meters towards the sea, while at distance of 100-150 meters blood clams populations were found, except in the station $\mathrm{V}$ and VI, blood clams populations were found at distance of 0-150 meters towards the sea. 


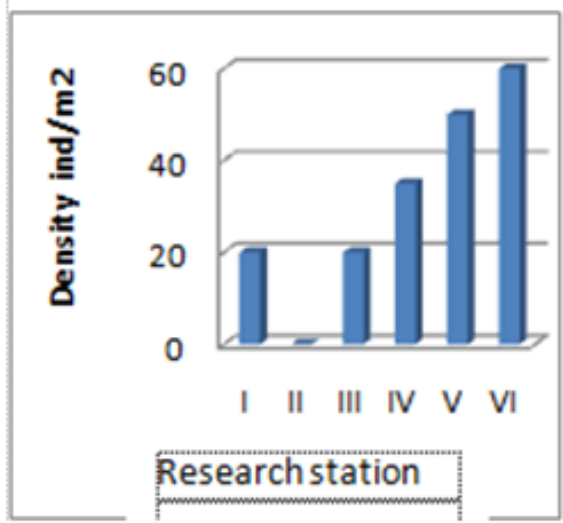

Figure 3. Population density of blood clams

At station II, blood clams population was not found. This was due to the station II had sand substrate texture and low organic material content as compared to other stations. Sand substrate texture is less suitable for the life of blood clams populations. This is in accordance with the research by Komala [10] in Teluk Lada that the highest density of blood clams populations were located on the dusty clay and sand dusty habitats. Broom [11] adds that the blood clams populations can live on sand substrate but their highest density was found in the mud substrate.

\subsection{Morphometric}

Overall percentage of variation category of clams' size in the research sites can be seen in (Figure 4. Shell length variation percentage) below:

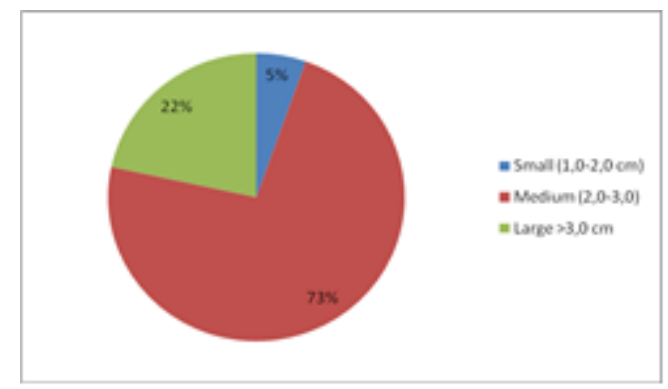

Figure 4. Shell length variation percentage

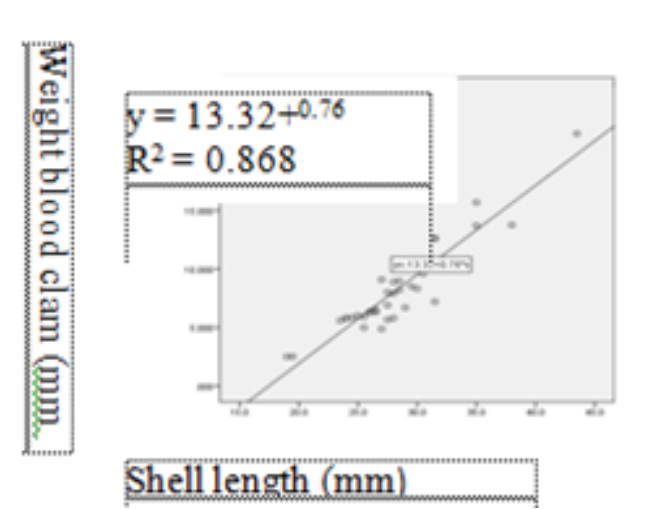

Figure 5. Relation between the length and weight of blood clams
Based on the measurement, the size of shell length was ranged from 19-43 mm. Refers to Figure 4, the percentage of shell size variation, blood clam populations were dominated by medium-size $(2,1 \mathrm{~cm} \mathrm{-} 3$ $\mathrm{cm})$, while the large size $(>3,1 \mathrm{~cm})$ were less found. Blood clams population with large size category was more common in station VI. According to the research by Mulki et al [12] in the coastal waters, Semarang, blood clams populations found were classified in medium size $(2,1$ to $3 \mathrm{~cm})$. The relation between the shells length and total weight of blood clams population can be seen in (Figure 5. Relation between the length and weight of blood clams) below.

The relation between shell length and total weight was expressed by $\mathrm{Y}=13,32+0,76$ with the relation coefficient $R^{2}=0868$. This showed that the increment of shells length will be followed by the increment of the total weight of the clams. Gimin et al. [13] stated that the growth of shells size to be clams become greater can be caused by the increment of shells mass.

The relation between shells length and total weight has a negative allometric growth pattern with value of $b$ $<3$. The negative allometric growth pattern indicated the dimensional shells growth was not comparable with the growth of their weight [13]. Effendy [9] added the value of $b<3$ showed the condition of the thin blood clams where the length increment was faster than the weight increment. There were three factors that affect the growth rate of clams i.e. temperature, food and reproduction activity [14].

The factor that caused the value of $b$ was the response difference of one species to the habitat [15]. While Abelha and Trivelto [16] stated that the b value was closely related with the differences in age, gonad maturity, sex, geographic and environmental conditions.

\subsection{Waters Quality Parameters}

The characteristics of the waters in research locations can be seen in Table 1 . The water quality parameters.

Table 1 . The water quality parameters.

\begin{tabular}{|c|c|c|c|c|c|c|c|c|}
\hline \multirow{2}{*}{$\begin{array}{l}\text { Enviroemental } \\
\text { Parameters }\end{array}$} & \multicolumn{6}{|c|}{ Stationa } & \multirow[t]{2}{*}{ tnit } & \multirow[t]{2}{*}{$\begin{array}{l}\text { Quality } \\
\text { Standards }\end{array}$} \\
\hline & I & II & III & IV & $V$ & $\mathrm{VI}$ & & \\
\hline Temperatast & 27.4 & 25.8 & 26.2 & 27.4 & 27.8 & 292 & ${ }^{\circ} \mathrm{C}$ & A satural \\
\hline $\mathrm{pH}$ & 6 & 6 & 6 & 7 & 7 & 7 & & 7.85 \\
\hline Solnity & 15 & 15 & 17 & 22 & 25 & 30 & Bot & A natural \\
\hline DO & 7.1 & 6.51 & 5.06 & 6.81 & 6.8 & 7.1 & $\mathrm{Ppm}$ & $>5$ \\
\hline Cuntent & 0.2 & 0.16 & 0.02 & 0.25 & 025 & 0.4 & $\mathrm{~ms}$ & - \\
\hline Bhightess & 6.6 & 6.6 & 7.8 & 13 & 1 & 2.5 & $\%$ & $>5$ \\
\hline
\end{tabular}

Description: Source KMLH [17]

Based on the observation that has been done, the highest temperature in the research location was $29,2{ }^{\circ} \mathrm{C}$ at station VI and the lowest temperature of $25,8^{\circ} \mathrm{C}$ was 
measured at station II. According to the research done by Khalil et al [18], temperature varies widely from 26,029,7 ${ }^{\circ} \mathrm{C}$ in Aman Island, 26,5-29,8 ${ }^{\circ} \mathrm{C}$ in Banda Aceh, and $28,7-29,9^{\circ} \mathrm{C}$ in Lhokseumawe.

$\mathrm{pH}$ in research locations was ranging from 6-7. This $\mathrm{pH}$ value was very suitable for the life of blood clams population. This was consistent with Gufran [19] that in general, the $\mathrm{pH}$ values in the range of 6-9 are optimal condition for the life of blood clams population.

The highest salinity was at station IV by 30 psu and lower salinity compared with others was at station I and III by 15 psu. Helm and Bourne [20] stated that bivalves can adapt to the salinity of 14-30 psu. According to research conducted by Khalil [18] in Banda Aceh, during the research, the salinity ranged from 25,2 to $31,1 \mathrm{psu}$, 26,5 to 31,5 and 29,1 to 31,8 psu respectively in Aman Island, Banda Aceh and Lhokseumawe. Salinity is very important in determining the distribution of blood clams and can affect the physiological processes of clam-blood for reproduction [18].

The highest stream velocity was $0,4 \mathrm{~m} / \mathrm{s}$ at station VI and the lowest was $0,02 \mathrm{~m} / \mathrm{s}$ at station III. According to Komala [10] the stream velocity in research sites was classified into weak current. Research done by Komala [10] in Teluk Lada found that the current was classified as weak to medium. According to Malvarez et al. [21[, the current derived from the amount of energy of the sea waves that spread to the sea shore will affect the size of the sediment. Weak water movement in muddy areas caused fine particles precipitated and abundant detritus, so it was a good medium for detritus eaters, as well as blood clams populations [22]. Siegel [23] added that the current velocity influenced the distribution of biota lived in the waters, i.e. bentos.

The lowest dissolved oxygen content was $5,06 \mathrm{mg} / \mathrm{l}$ at station III. While the highest was found at station 1 and VI with a value of 7,1 mg/l. According to Minister of Environment (2004), in general, dissolved oxygen content at each observation stations including optimal conditions for the survival of marine life. According to the research by Komala [10], the dissolved oxygen content in Teluk lada was ranging from 6,64 to $7,27 \mathrm{mg}$.

\subsection{Sediment and Organic Materials}

Based on the results, sediment and organic materials content on the research sites that have been analyzed in Chemical, Biology and Soil Fertility Laboratory can be seen in Table 2.

Table 2. Sediment and organic materials content texture

\begin{tabular}{|c|c|c|c|c|}
\hline \multirow{2}{*}{$\begin{array}{l}\text { Researth } \\
\text { trition }\end{array}$} & \multicolumn{3}{|c|}{ 9, The Fration Of Tetsint } & \multirow{2}{*}{$\begin{array}{l}\text { Orgzaic } \\
\text { Vaterials\% }\end{array}$} \\
\hline & Sand & Dust & dayey & \\
\hline I & 29,92 & 43,10 & 2698 & 392 \\
\hline II & 100 & 0 & 0 & 020 \\
\hline II & 4,52 & 83,09 & 12,39 & 2,13 \\
\hline N & 8,76 & 71,57 & 19,67 & 266 \\
\hline V & 7,11 & 76,07 & 1682 & 240 \\
\hline VI & 10,06 & 73,5 & 16,69 & 3,40 \\
\hline
\end{tabular}

At station I, with clay substrate and station III, IV, $\mathrm{V}$ and VI which were dominated by dusty clay substrate. Meanwhile, station II had sand substrate. From the research done by Arkhrianti et al [24] blood clams population was living on mud habitat. According to Veiga et al. [25], substrate is one of factor that can influence the spread pattern of blood clams, because besides serving as living place, it also serves as landfilling of nutrients (as a food source provider), a gathering place for organic materials and shelter organisms from the threat of predators. Substrate texture and organic content in the sediment are important factors for blood clams [26].

From the results, it was found that the lowest organic content of $0,20 \%$ at station II, while the higher organic content of $3,92 \%$ was at Station I and 3,40\% at station VI. Organic materials are primary food source for blood clams [27]. Blood clams population was an organism lived by immersing themselves in the substrate and obtain food by filtering small particles such as phytoplankton, zooplankton and organic materials [28].

\subsection{Relation between Waters Parameters and Density of Blood Clams}

The results from several environmental parameters were analyzed using multivariable statistical analysis, based on the PCA. The results of PCA on the environmental parameters in the correlation matrix showed that the critical information that described the correlation between parameters, centered on two main axes; F1 (horizontal axis) and F2 (vertical axis) as shown in Figure 5. From the figure we can see the information presented by both axes of each $\mathrm{F} 1$ by $57,17 \%$ and $\mathrm{F} 2$ by 21,04\%, so from both axes, variety of Anadara Granosa blood clams habitat characteristics at each station can be explained by both main axes of $78,21 \%$ from the variance total. F1 axis was the main factor that explain better the variability of the data source, while the second axis (F2) explain better the residue variability which was not represented on the main factors. Quality of the representation from variables on the axis was directly evaluated by looking at the variable distance to the axis, where the stronger correlation (positive or negative), the closer the variables distance to the axis [29].

As seen from the Figure 6, the environmental parameters affected the blood clams population on axis 1 was characterized by six variables: Clay $(0,72)$, organic 
$(0,74)$, dust $(0,88)$, temperature $(0,77)$, salinity $(0,73)$ and $\mathrm{pH}(0,78)$. Clay, organic and dust variables contributed quietly great to the formation of the major axis negative F2 of the brightness variable $(-0,11)$ and sand $(-0,92)$. Figure 6 above showed that the sand variable was inversely proportional to clay, dust and organic. This showed that the high sand may cause the value of clay and organic becomes low. In Figure 6 above, it shows that all sixth station observed have different tendency characteristics as seen from habitat grouping based on the similarity of physical parameter characteristics of water environment and the measured substrate. Some environmental parameters form a group that characterizes each research station. The first group of stations I and III was characterized by brightness parameters. The second group of station II was characterized by high sand substrate parameters. The third group of station VI was characterized by temperature, salinity, $\mathrm{pH}$, flow, DO. The fourth group of stations IV and $\mathrm{V}$ were characterized by clay, dust and organic.
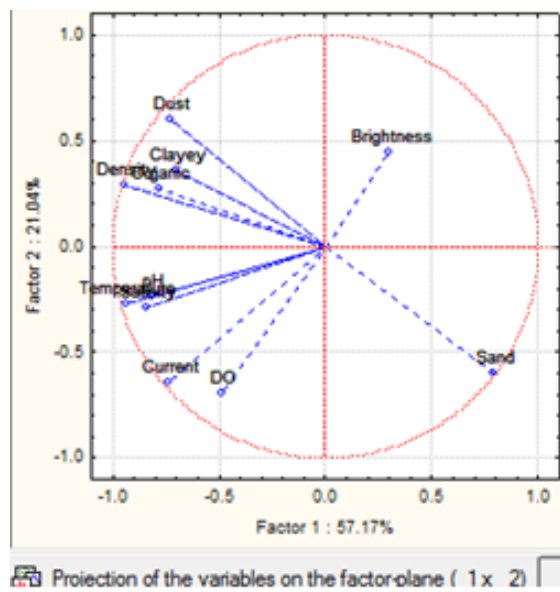

(a)

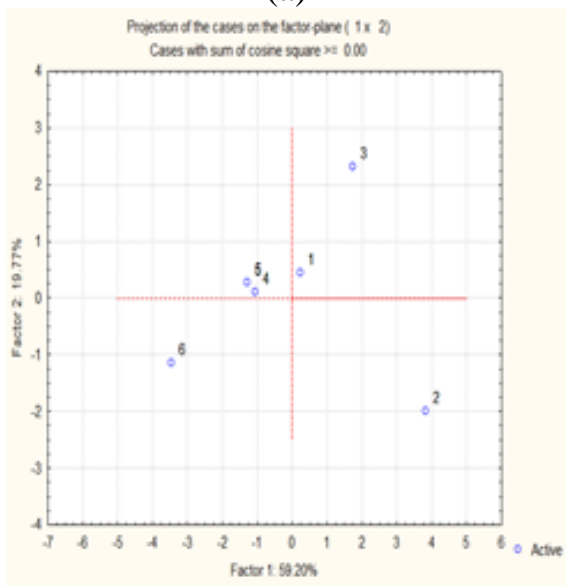

(b)

Figure 6. Principal Component Analysis Graph

The highest population density of blood clams as compared to other stations were located at station VI with dusty clay habitat texture and contain higher organic materials. This condition was inversely proportional with station II which has a sand substrate with low organic materials content. Furthermore, the location close to the fisherman village add the pressure on blood clams populations in these locations, so the blood clams populations were not found in these locations. This was in agreement with Broom [11] that stated that the blood clams populations can survive on sand substrate but their amount was not as many as in muddy substrate.

\section{Conclusions}

1. Blood clams populations in research sites were found in the boundary waters of 0-100 meters towards the sea, then $>100$ meter blood clams populations cannot be found, except at station IV, V and VI where blood clams populations were found in the boundary waters of $0-150$ meters.

2. The highest density of $60 \mathrm{ind} / \mathrm{m}^{2}$ was found in station VI, while the density in station I and III was lower than the other stations $\left(20 \mathrm{ind} / \mathrm{m}^{2}\right.$

3. Shell length variations found during the research were classified into medium size and growth pattern between the length and the total weight of the negative allometric.

4. The results of PCA analysis of clay, dust and organic habitat textures as well as physical chemistry parameters of the waters (temperature, salinity, $\mathrm{pH}$ ) were factors that affect the density of blood clams.

\section{References}

[1] Alkarkhi, F.M.A., Ismail,N., Easa, A. M. 2008. Assessment of arsenic and heavy metal contents in cockles (Anadara granosa) using multivariate statistical techniques. Journal of hazardous materials 150 (2008) 783-789.

[2] Hazmi, A. J. A., Zuki, A. B. Z., Noordin, M. M., Jalila, A., Norimah, Y. 2007. Mineral composition of the cockle (Anadara granosa) shells of west coast of peninsular Malaysia and it's potential as biomaterial for use in bone repair. Journal of Animal and Veterinary Advances 6 (5): 591-594.

[3] Dong, M. F. 2001. The nutritional value of shellfish. Available at: www.wsg.washington.edu.,p.1-8.

[4] Septifitri., Monintja, D. R., Wisudo, S. H., Martasuganda, S. 2006. The Development Opportunity of Catch Fishery in the Province of Southern Sumatera. Jurnal Teknologi Perikanan dan Kelautan. Vol 1. No 1. November 2010: 81-9.

[5] KKP. 2013. Indonesia's fisheries statistics, 2012. Directorate General of Fishing. Vol 13 No 1.

[6] Bouyocos, G. J. 1926. The hydrometer as a new and rapid method for determining the colloidal contents of soils. Michigan agriculture experiment station.

[7] Clarke, K., R. Warwick. 2001. Change in marine communities: an approach to statistical analysis and interpretation. 2nd ed. United Kingdom: primer-e ltd. 
[8] Karnik, S. N and S. K. Chakraborty. 2001. LengthWeight Relationship And Morpometrich (Mollusca Cephalopoda) Of Mumbay (Bombay) Indian Journal Of Marine Sciences. Vol. 30 (4). Desember 2001, tp. 261-263.

[9] Effendy, M. I., 1997. Fisheries Biology. Foundation library of archipelago. Yogyakarta.

[10] Komala, R. 2012. Ekobiologi analysis as the basis for resource management mussels blood (Anadara granosa) in Teluk Lada Sunda Strait. Thesis. Institut Pertanian Bogor.

[11] Broom, M. J. 1985. The biology and culture of marine bivalve mollusca of The genus Anadara. ICLARM.Manilla Phillipiness. 370.

[12] Mulki, A. R., Suryono, C. A., Suprijanto, J. 2012. Variasi Ukuran Kerang Darah (Anadara granosa) di Perairan Pesisir Kecamatan Genuk Kota Semarang. Journal of Marine Research. Volume, Nomor, Tahun 2014, Halaman 122-131

[13] Gimin, R., R, Mohan., L.V. Thinh., and A.D. Griffths. 2004. The Relationship Of Shell Dimensions and Shell Volume TO Live Weight and Soft Tissue Weight In The Mangrove Clam, Polymesoda erosa (Solander, 1786) From Northern Australia. NAGA, WorldFish Center Quarterly Vol. 27 No. 3 \& 4 Jul-Dec 2004.

[14] Jamabo NA, AC Chindah, JF Alfred Ockiya. 2009. Length-Weight Relationship of a Mangrove Prosobranch Tympanotonus fuscatus var fuscatus (Linnaeus 1758) From the Bonny Estuary, Niger Delta. Nigeria. World Journal of Agricultural Sciences 5(4): 384-388

[15] Patimar, R, M Yousefi, SM, Hosieni. 2009. Age, Growth and Reproductive of The Sand Smelt Atherina boyeri Risso, 1810 in the Gomisha Wetland- Southeast Caspian Sea. WWW J Est Coast dan Shel Sciences. 81(457-462).

[16] Abelha MCF, Erivelto D. 2008. Population Structure, Condition Factor and Reproductive Period of Astyanax paranae (Eigenmann, 1914) (Osteichthyes: Characidae) in a Small and Old Brazilian Reservoir. J. Braz Arch Biol and Tech 51: 503-512

[17] KMNLH. 2004. Decree of the Minister of State for Population and the Environment No. 51 in 2004. The quality standard of sea water for marine and aquaculture. Jakarata. $6 \mathrm{hlm}$.

[18] Khalil, M. 2010. The effect of environmental condition on the spawning period of blood cockle Anadara granosa (bivalvia: arcidae) in Lhokseumawe, the Northern Straits Of Malacca. Jurnal agrium. volume 10 nomor 2, september 2013.

[19] Ghufran, M. H., Kordi, K., Tancung, A. B. 2007. Management of water quality in aquaculture. Rieneka cipta.

[20] Helm, M. M., Bourne, N. Lovatelli, A. 2004. Hatchery Culture of Bivalves. A Practical Manual.
FAO Fisheries Technical Paper. No. 471. Rome. $177 \mathrm{p}$.

[21] Malvarez, G. C., Cooper, J. A. G., Jackson, D. W. T. 2001. Relationships between wave-induced currents and sediment grain size on a sandy tidalflat. Journal of sedimentary research. September 2001.

[22] Mann, K. H. 2000. Ecology of coastal waters with implications for management 2 rd edition. Blackwell Science, Inc. USA.

[23] Siegel, D. A., Kinlan, B. P., Gaylord., Gaines, S. D., 2003. Lagrangian descriptions of marine larval Dispersion. Marine Ecology Progress Series. Vol. 260: 83-96, 2003.

[24] Arkhrianti, I., Bengen, D. G., Setyobudiandi, I. 2014. Spatial distribution and habitat preference of bivalvia in the coastal waters of simpang pesak sub district, east belitung district. Jurnal Ilmu dan Teknologi Kelautan Tropis, Vol. 6, No. 1, Hlm. 171-185.

[25] Veiga, P., Rubal, M., Cacabelos, E., Maldonado, C., Pinto, i. S. 2014. Spatial variability of macrobenthic zonation on exposed sandy beaches. Journal of Sea Research 90 (2014) 1-9.

[26] Ellingsen, k. E., 2002. Soft-sediment benthic biodiversity on the continental shelf in relation to environmental variability. Marine ecology progress series. vol. 232: 15-27, 2002

[27] Sundaravarman, K., D. Varadharajan, A. Babu, A. Saravanakumar, S. Vijayalakshmi, T. Balasubramania. 2012. A Study of marine benthic fauna with spacial reference to the environmental parameters, South East Coastal of India. International Journal of Pharmaccutical \& Biological Archives, 3(5): 1157-1169.

[28] Burkhardt, W. \& Calci, K.R. 2000. Selective accumulation may account for shellfish associated viral illness. Applied and Environmental Microbiology 66(4): 1375-1378.

[29] Bengen, D. 2000. Synopsis: Engineering sampling and analysis of biophysical data coastal resources. The center coastal and marine resources. Institut Pertanian Bogor. 